\title{
WHY THE MUSEUM
}

\author{
Konstanty Gebert \\ Periodista \\ Taube Center \\ Warsaw, Poland \\ konstanty.gebert@g.pl
}

\begin{abstract}
RESUMEN
El artículo discute el contexto de la creación del nuevo Museum of the History of Polish Jews que abrirá sus puertas en Varsovia, Polonia, en el año 2010.

Analiza la desaparición de la historia judía de la memoria polaca después de la Shoa, la importancia de esa historia para los polacos y judios por igual y el impacto que el museo debería tener para un entendimiento más profundo de una historia a la vez compartida y controvertida,
\end{abstract}

Palabras Clave: Polonia, historia judia, museos.

\begin{abstract}
The article debates the context of the creation of the Museum of the History of Polish Jews which is to open in Warsaw, Poland, in 2010. It analyzes the disappearance of Jewish history from Polish memory after the Shoah, the importance of that history for Poles and Jews alike, and the impact the museum should have for a deepened understanding of their shared, if contested past.
\end{abstract}

KEY WORDS: Poland, Jewish history, museums.

This time it is official. The Museum of the History of Polish Jews, dreamt about for more than a decade, officially established in 2005 , and which had its cornerstone laid in 2007 , will open its doors in 2011 . Construction will probably begin in 2008, and the final details of the exposition are now being worked out. Once completed, it will be Poland's most modern museum, and the only one in the world to be dedicated to the history of Polish Jews: not only the dark years of the Shoah, but the glorious 700 of Polish Jewish civilization which preceded it, as well as the post-war attempts, tenacious if often stymied, to continue a Jewish presence in what for ages had been the only homeland the Jews had. 
The museum is the brainchild of a group of historians connected with Warsaw's Jewish Historical Institute. It is a State/private partnership - a novel development in Poland-between the Polish state which had provided the first $\$ 20$ million in funding (the museum is expected to cost at least $\$ 100$ million), and the Association which runs the Institute and is responsible both for the project and for fundraising for it worldwide. An international committee, under the conjoint aegis of the Presidents of Poland, Israel and Germany, supervises the project. The City of Warsaw has allocated, free of charge, the plot of land on which the museum will be built. It will stand in the heart of what was the city's Jewish district, turned into a ghetto during the war by the Nazis. Completely razed after the Uprising of 1943, this part of the city was rebuilt after the war in a drab, Stalinist style. A huge plaza in its center surround's Nathan Rappaport's monument to the heroes of the Uprising, unveiled in 1948. The museum will stand at the other end of this plaza.

The museum will be much more than just an institution of education and research. It has, in fact, the potential to become an important factor shaping the way Poland understands its past, and thus also builds its present and faces its future. In order to understand that, it is necessary to turn to that past, and closely examine some of its aspects.

Throughout its entire post-war history, Poland has struggled with the memory of its Jewish past. The issue of having witnessed the most devastating genocide in human history, committed by the Germans on Polish soil, and in front of millions of Polish witnesses, would have by itself been hard enough to deal with; human societies do not witness genocides and then continue with business as usual. The memory remains, in the stories told and untold, and in the nightmares. Though this burden alone would have been hard to bear, it became compounded by the fact that many Poles had participated in the genocide, or profited from it. The horror was therefore unavoidably informed by guilt - but also by legitimate pride: Poles make up the single largest group of Yad Vashem's Righteous Among the Nations.

Yet, alongside the heroic attempts of dozens of thousands of saviors, there was also a secret and shameful glee among many for finally having been freed of the "Jewish question" which, in the pre-war years, had come to be seen by a majority of Polish society, thanks to the relentless propaganda of nationalists and Catholic fundamentalists, as the most important issue the country faced. This glee was more widespread even than the guilt, making any discussion of what actually had happened almost impossible. How to speak of the genocide and not deplore it? Yet-how to deplore the genocide while secretly being glad for its end result?

All this would have made any meaningful discussion of Polish Jewish history, not only of the war-time years, but of the nine centuries of Jewish life which had preceded them, next to impossible. France, for instance, which had faced similar problems of memory as Poland did, alleviated, it is true, by the fact that the Jewish death toll was less by orders of magnitude, but compounded by the fact that not only many individual Frenchmen, but the French State itself, had participated in the crime, struggled to come to terms with it for half a century. Yet France had a double advantage on Poland in that respect: not only it had emerged from the war badly wounded only, and not broken, but, even more importantly, it emerged from it a free country. Poland, on the other hand, had lost almost 6 million dead (more than half of them Jewish), or $16 \%$ of its population, to France's 560 thousand, or $1,35 \%$ - and emerged from Nazi terror to fall 
victim to Soviet occupation. The war that had started over Poland's independence ended with the country losing it again. The Polish Communist regime the Soviets had set up was bloody, brutal and hostile to free discussion. The country was far too traumatized to be able to engage in much intellectual introspection anyway -but, when it tried to nonetheless, it found itself muzzled by the Communist censor.

Communism not only stifled debate, but twisted and perverted it as well -and few topics became as twisted and perverted as the Jewish past. Before the war, the Communists had been a small but outspoken adversary of the then pervasive anti-Semitism and, in their post-war onslaught on Poland's rights as well as its wrongs, repeatedly condemned all of the country's pre-war political regimes as "Fascist anti-Semites". The reality had, however, been somewhat more differentiated and less condemnable, and this made the Polish anti-Communist majority feel that Poland itself was being branded that way by its new masters, and branded unfairly. To compound this quandary, Polish Communists of Jewish origin were quite prominent amongst these new masters, something that was almost impossible before the war. Apart from members of Parliament from the different Jewish parties, always in the opposition, not only there had not been before almost no Jews among the nation's political elite, but even a Jewish provincial stationmaster would have been an oddity. Thus, and for similar reasons, an average Pole in the late Forties looked at the ethnic mix of Poland's new political elite somewhat like a white Alabamian from the same period would have looked at the present racial mix of that State's political leadership -a Jewish minister just as unpleasantly surprising as a Black governor. But the Communists, isolated and lacking legitimacy, went simultaneously to great lengths to conceal, or gloss over, the fact that Jews were prominent in their leadership, as they knew this made them even less legitimate in the eyes of a majority of Poles. This in turn had lead to an instrumental ban on the discussion of all things Jewish, apart from cases which suited the leadership politically. And finally, quite a few of the non-Jewish Communists, especially from among the opportunists who had flocked to the party in power, were themselves anti-Semitic, a fact which would reveal itself with a vengeance in the "anti-Zionist" campaign of 1968.

Finally, the small -and, due to emigration, shrinking still more- community of Jewish survivors lived in the early post-war years essentially in separation from Polish society at large. This was due to wartime trauma, the very real fear of post-war anti-Semitic murder (at least several hundred, possibly several thousand Jews were killed in the Forties) -and to the fact that, in contradistinction to that society, the Jews had largely, and publicly, thrown their lot in with the new regime. This was hardly surprising: not only the regime was the only force which could provide some security against anti-Semitic murderers, but it openly declared, and implemented, a policy of non-discrimination. Those Jews who, for political, social, national or religious reasons could not countenance living under Communism, or remaining in Poland for whatever reason, left, initially legally, then illegally. Those who remained were, in their majority, at least reconciled with the new regime, while it was rejected by a majority of their ethnically Polish co-citizens. For all those reasons, Jews did not participate, as Jews, in such post-war Polish debate on Jewish issues as there was. With the passing of time, the remaining Jews, who already were overwhelmingly assimilated, as opposed to what had obtained before the war (the non-assimilated Jews had been immediately recognizable, and for that reason had little chance to survive the Germans and their collaborators), saw themselves as Poles, acted as Poles, and gradually, their Jewish identity 
shredded, became entirely Polonized- not only in their own eyes, but also in the eyes of society at large. This meant, however, that no specifically Jewish voices could be heard any more, even if such an expression would have been allowed, and therefore there could not be a counterweight to distorted ideas. The Poles were left to debate myth against myth -among themselves.

In a nutshell: since the war, the Poles were, for complicated reasons involving guilt, shame and fear, uneasy in discussing things Jewish. These were, furthermore, not their main concern: the country, devastated by the war, was undergoing a second trauma due to the brutal nature of Soviet occupation and the Communist regime it had imposed. This regime, in turn, stifled and perverted what debate there was, while its own attitude towards Jews was internally contradictory. Furthermore, Jewish voices, again for separate complicated reasons, were all but absent from that debate. Under these circumstances, it is hardly surprising that things Jewish simply disappeared from public awareness; the topic became taboo. The "anti-Zionist" campaign of 1968 vociferously, if briefly, changed that state of affairs -obviously for the worse, perverting even further what already had been twisted. From the second half of the Seventies onwards, however, a new generation born after the war became more and more interested in things Jewish, and brought them again to public attention, this development concomitant with, and furthered by, the rebirth of the democratic opposition which produced Solidarity and eventually brought about, in 1989 , the end of Communism. But by then the damage had already been done.

Apart from a brief mention here and there, the history of Polish Jewry disappeared from school and university textbooks of Polish history, from guidebooks to formerly often significantly or predominantly Jewish town, and from public awareness. The Communists reveled in what they considered one of their main successes -the new ethnic unity of Poland- and for once nobody challenged them. Not only the Jewish origins of many a Communist politician became unmentionable; the same became true of the biographies of outstanding figures of Polish sciences, art and letters, including some of the country's most beloved poets, though they themselves might have been intensely Jewish. What remained of Jewish monuments, orphaned after the murder of those who had lived or prayed there, gradually decayed. Cemeteries became dumps or construction sites, synagogues were converted into storage facilities, sports clubs or, at best, library or museum buildings. The history of the war was rewritten, its Jewish victims becoming anonymous "Polish citizens", the Shoah merely a footnote to the -only too real- "suffering of the Polish nation at the hands of the Hitlerites". The Auschwitz site was officially named "Museum of the martyrology of the Polish nation and other nations"; in the list of the latter, Jews were mentioned last, the Polish word for Jew conveniently beginning with the last letter of the Polish alphabet. The only remaining visible sign of nine centuries of history -Nathan Rappaport's towering monument to the heroes of the ghetto uprising in Warsaw-stood on the central square of a new housing development which had grown around it, out of the ruins of the ghetto. It became almost impossible to understand why it had been built in the first place.

And yet it is obviously impossible to understand not only the monument, not only Warsaw, but the history of Poland itself - without the Jews. From the first mentions of the country by early mediaeval Jewish chroniclers and the first coins ever minted there by Jewish minters, through the grandiose history of the golden age of the Polish Commonwealth, with its Va'ad Arba Artzot, the (Jewish) Council of the Four Lands (of Poland), the only Jewish executive political body that 
existed between the destruction of the Second Temple and the creation of the Jewish Agency in Palestine, through the glory of the Baal Shem Tov and of the Vilna Gaon, through the bravery of Jewish militants, such as Berek Joselewicz or Feliks Perl, fighting for their country's independence during the long era of the Poland's partition, to the poetry of Julian Tuwim, the prose of Isaak Bashevis Singer and the music of Arthur Rubinstein - the Jews have been an integral part of Poland. Not as tolerated guests, or secondary actors, but as co-shapers of the country, by far not only victims, but proud builders. Even in the increasingly anti-Semitic climate of inter-war Poland, this fact had been impossible to deny-but its awareness has been lost in the horror of the Shoah and the trauma of the Communist period which had followed.

Since Poland had recovered its independence in 1989, as a democratic country, part of Europe again and a friend of the US and of Israel, much had been done to change this sorry state of affairs. Literally hundreds of books of Jewish interest had been published, the Jewish Culture Festival in Cracow has become the continent's largest, and hundreds of Polish scholars, writers, journalists and community activists have produced an impressive array of works, from scientific monographs through journalistic debates to local commemorations of the memory of neighbors lost. Public debates about the crimes of the past - honest now, and daring - attract widespread attention and passion.

In just one case - the debate around Jan T. Gross ground-breaking book "Neighbors", describing the wholesale wartime massacre of Jews by their Polish neighbors in the town of Jedwabne - a stunning $85 \%$ declared in a poll to be following it. The renascent Jewish community, through its recovered synagogues, schools and organizations, and events addressed to society at large, is very much part of this vibrant cultural scene. Though anti-Semitism, as evidenced throughout that period, is shamefully far from dead, there is among the Poles today a growing thirst for knowledge about their country's Jewish past, without which they cannot fully understand nor their country, nor themselves. Yet it will take years of hard work to undo the legacy of the past - and resources are scant and few.

To be sure, the average Polish citizen today can partially satisfy this thirst through reading novels, participating in events, visiting restored sites. Yet Jewish contents filters but slowly to the history textbooks his children use, the local museum will at best have a case or two of the precious few Jewish artifacts which have survived the $20^{\text {th }}$ century, and his best chance to see a Jew is when he watches movies. For all the genuine interest, things Jewish are still sidelined - not by hostility this time, but simply by the absence of things to show, and places to show them. This legacy of the Nazi and Communist past, detrimental to Poles and Jews alike, cannot be allowed to stand.

The Museum of the History of Polish Jews intends to change this. Once opened, on the plaza on which Rappaport's monument, no longer incongruous then, stands, it will attract hundreds of thousands of visitors each year. It will compensate for the shortage of artifacts by stunning visuals and video displays. It will make up for the silence and distortions of the past by exhibitions and public debates, in which the memory of the glory of Polish Jewry will be brought back to life. Though this is, and rightly so, a Polish, not a Jewish institution: Poland has a legitimate interest in reclaiming its Jewish heritage, the Museum will, by closely cooperating with the 
Jewish community, ensure that Jewish history will no longer be marginalized, but returned to its legitimate place of pride. Of pride for Poles and Jews alike.

Museums are obviously about the past - but this one is also about the present and the future. It will bring back to Jews and Poles that what they have been robbed of: the memory of a common past, of triumphs shared and disasters experienced together. Nor will it gloss over the horrors of the past, including those committed by neighbors against their Jewish neighbors, for only their frank exposition can ensure that they will not be ever repeated. The spontaneous outburst of interest in, and sympathy for, things Jewish in the Polish democratic opposition movement, and the staunch condemnation of anti-Semitism by most of Polish society in the years that followed the fall of Communism, clearly indicate that what the Museum stands for is not some foreign import, but a reflection of values deeply engrained in the collective soul of modern Poland. And the love shown for their country by Jewish militants and political prisoners in the times of the underground movement, as well as by many among the Polish Jewish diaspora who supported it - and now support the Museum - shows that these values are reciprocated. The Museum can, and will, be a place in which the two strands of Polish history, the Polish and the Jewish one, brutally separated by a horrible past, can intertwine once again - to help build a future of hope. 